\title{
Pronounced Ptosis in Myasthenia Gravis-A New Bedside Clinical Sign
}

\author{
Pulikottil W. Vinny ${ }^{1}$ Venugopalan Y. Vishnu²,๑ \\ ${ }^{1}$ Department of Neurology, Indian Naval Hospital Ship Asvini, \\ Mumbai, Maharashtra, India \\ 2Department of Neurology, All India Institute of Medical Sciences, \\ New Delhi, Delhi, India
}

\begin{abstract}
Address for correspondence Pulikottil W. Vinny, MD, DM, Department of Neurology, Indian Naval Hospital Ship Asvini, Mumbai 400005, Maharashtra, India (e-mail: vinnywilson@gmail.com).
\end{abstract}

J Neurosci Rural Pract 2021;12:410-411.

\begin{abstract}
Keywords

- myasthenia gravis

- ptosis

- blepharoptosis

- lid signs

- clinical neurology

We report three cases of myasthenia gravis in whom the asymmetrical ptosis at presentation became more pronounced with the described bedside technique. Pronounced ptosis could be elicited by making the patient speak continuously for up to 2 minutes. Pauses for breathing and natural blinking were allowed. The sign is best elicited in newly diagnosed and treatment-naive patients. The loss of compensation for ptosis by frontalis muscle due to speech-induced fatigue may be responsible for the observed effect. Patients' symptoms abated on treatment with acetylcholine esterase inhibitors, steroids, and steroid-sparing agents.
\end{abstract}

\section{Introduction}

The ocular manifestations in myasthenia gravis stem from ineffective neuromuscular transmission. These ocular signs involve demonstrating or enhancing, lid abnormalities, and/ or ophthalmoplegia..$^{-3}$ The common signs are asymmetrical ptosis and ophthalmoplegia. Other signs include "curtain sign," "peek sign," "lid twitch," pseudo internuclear ophthalmoplegia, abnormal saccadic movements, gaze palsies, vertical nystagmus, lid retractions, and lid oscillations. ${ }^{1-3}$ Ice pack test and neostigmine challenge demonstrate reversal of ptosis and ophthalmoplegia by improving the efficiency of neuromuscular transmission. We describe three cases of myasthenia gravis in whom "pronounced ptosis" was demonstrated using a specified maneuver with discussion on the possible underlying mechanism.

\section{Technique}

"Pronounced ptosis" is demonstrated by making a patient of myasthenia gravis speak continuously (e.g., counting from 1 through 100) in primary gaze. The act of speaking should be uninterrupted for approximately 2 minutes. Pauses for breathing and natural blinking may be allowed. This maneu-

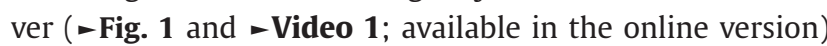
results in preexisting ptosis becoming more pronounced. The more affected eye may even close completely while ptosis in the less affected eye becomes more pronounced. The sign is the best elicited when the patient has been newly diagnosed and is treatment naïve.

\section{Case 1}

A 75-year-old male presented with neck weakness (extensor > flexor) and bilateral asymmetrical ptosis of 2 weeks duration. Symptoms worsened as the day progressed. Toward evening patient tended to support his chin with his hands. His single breath count was 40 . He showed "pronounced ptosis" (right eye closed completely while ptosis increased in left eye) as he counted from 1 through 100 ( - Video $\mathbf{1}$; available in the online version). Repetitive nerve stimulation (RNS) of facial and spinal accessory nerves showed a decremental response. On Neostigmine challenge, ptosis improved, partially in the right eye, completely in the left eye along with published online January 13, 2021
DOI https://doi.org/

10.1055/s-0040-1721559 ISSN 0976-3147. (c) 2021. Association for Helping Neurosurgical Sick People.

This is an open access article published by Thieme under the terms of the Creative Commons Attribution-NonDerivative-NonCommercial-License, permitting copying and reproduction so long as the original work is given appropriate credit. Contents may not be used for commercial purposes, or adapted, remixed, transformed or built upon. (https://creativecommons.org/licenses/by-nc-nd/4.0/)

Thieme Medical and Scientific Publishers Pvt. Ltd., A-12, 2nd Floor, Sector 2, Noida-201301 UP, India 


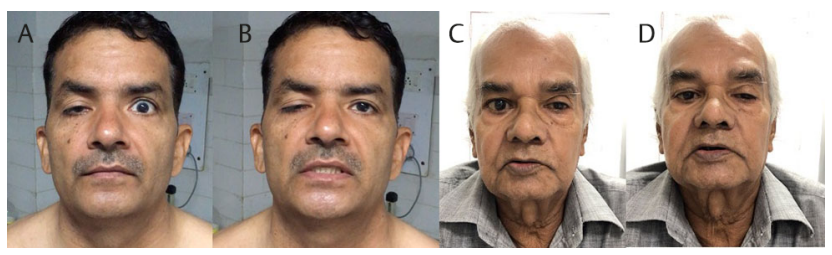

Fig. 1 Cases 2 ( $\mathbf{A}$ and $\mathbf{B}$ ) and 3 ( $\mathbf{C}$ and $\mathbf{D}$ ) showing pronounced ptosis while speaking continuously for 2 minutes.

improvement in the power of neck muscles. Serum showed elevated AchR antibodies (16.63 nmol/L; normal $<0.25 \mathrm{nmol} / \mathrm{L}$ ). The patient is presently asymptomatic on treatment (prednisolone: $30 \mathrm{mg} /$ day, azathioprine: 150 $\mathrm{mg} /$ day, and pyridostigmine: $180 \mathrm{mg} /$ day).

\section{Video 1}

A video showing pronounced ptosis in case 1 . Online content including video sequences viewable at: https:// www.thieme-connect. com/products/ejournals/html/10. 1055/s-0040-1721559.

\section{Case 2}

A 48-year-old male presented with ptosis in the right eyelid, nasal intonation of voice and dysphagia which worsened toward evening. His ptosis improved partially with ice pack test and neostigmine challenge. Patient's right eye showed "pronounced ptosis" on loud counting ( - Video 2 [available in the online version] and - Fig. 1A and $\mathbf{B}$ ). RNS of facial nerve showed decremental response. Serum showed elevated AchR antibodies. (19.9 nmol/L; normal <0.25 nmol/L). Presently, patient is asymptomatic on pyridostigmine (180 mg/day), prednisolone (10 $\mathrm{mg} /$ day), and mycophenolate sodium (720 mg/day).

\section{Video 2}

A video showing pronounced ptosis in case 2. Online content including video sequences viewable at: https:// www.thieme-connect. com/products/ejournals/html/10. 1055/s-0040-1721559.

\section{Case 3}

A 73-year-old male presented with ptosis in the left eye and double vision of 1-year duration. His symptoms accentuated as the day progressed. The double vision worsened on looking to the right and up, resulting from a right lateral rectus palsy. On counting loudly from 1 through 100, ptosis in left eye became pronounced ( $\mathbf{- V i d e o} 3$ [available in the online version] and - Fig. 1C and D). Application of ice pack showed improvement in ptosis. RNS of the facial nerve showed a decremental response. Neostigmine challenge (2-mg intramuscular) resulted in improvement in ptosis and partial resolution of double vision. The patient has been initiated on tablet prednisolone: $10 \mathrm{mg} /$ day, azathioprine: $150 \mathrm{mg} /$ day, and pyridostigmine: $180 \mathrm{mg} /$ day. His symptoms have abated on treatment.

\section{Video 3}

A video showing pronounced ptosis in case 3. Online content including video sequences viewable at: https:// www.thieme-connect. com/products/ejournals/html/ 10.1055/s-0040-1721559

\section{Discussion}

The pathophysiologic mechanisms underlying the "pronounced ptosis" may involve an overactive frontalis muscle. A review of literature did not reveal previously reported cases demonstrating the described sign. Ipsilateral frontalis contraction provides compensation for ptosis in myasthenia gravis patients. ${ }^{4}$ Facial innervated muscles are known to be affected by inefficient neuromuscular transmission in myasthenia gravis. ${ }^{5}$ In myasthenia gravis, frontalis muscle supplied by facial nerve may get fatigued during the act of prolonged speaking. We believe that this speech induced fatigue of frontalis muscle results in loss of compensation for ptosis, thus pronouncing ptosis. A similar mechanism has been proposed for enhanced ptosis during sustained up gaze in patients of myasthenia gravis. ${ }^{3}$

\section{Authors' Contributions}

P.W.V. drafted the manuscript, management of the patient, described the sign, and explanation for clinical sign. V.Y.V. edited the manuscript, independent validation of sign, and provided explanation for the clinical sign.

\section{Funding}

None.

\section{Conflict of Interest}

None declared.

\section{References}

1 Gilhus NE, Tzartos S, Evoli A, Palace J, Burns TM, Verschuuren JJ. Myasthenia gravis. Nat Rev Dis Primers 2019; 5(1):30

2 Al-Haidar M, Benatar M, Kaminski HJ. Ocular myasthenia. Neurol Clin 2018;36(2):241-251

3 Gorelick PB, Rosenberg M, Pagano RJ. Enhanced ptosis in myasthenia gravis. Arch Neurol 1981;38(8):531

4 Juel VC, Massey JM. Myasthenia gravis. Orphanet J Rare Dis 2007;2:44

5 Witoonpanich R, Barakul S, Dejthevaporn C. Relative fatigability of muscles in response to repetitive nerve stimulation in myasthenia gravis. J Med Assoc Thai 2006;89(12):2047-2049 